\title{
New Insights in the Mechanisms of Impaired Redox Signaling and its Interplay With Inflammation and Immunity in Multiple Sclerosis
}

\author{
Danica MICHALIČKOVÁ ${ }^{1}$, Martin ŠÍMA ${ }^{1}$, Ondřej SLANA $\check{R}^{1}$ \\ ${ }^{1}$ Institute of Pharmacology, First Faculty of Medicine, Charles University in Prague and General \\ University Hospital in Prague, Prague, Czech Republic
}

Received August 2, 2019

Accepted October 29, 2019

Epub Ahead of Print December 19, 2019

\begin{abstract}
Summary
Multiple sclerosis (MS) is an autoimmune neurological disease characterized by chronic inflammation of the central nervous system (CNS), leading to demyelination and axonal damage and resulting in a range of physical, mental or even psychiatric symptoms. Key role of oxidative stress (OS) in the pathogenesis of MS has been suggested, as indicated by the biochemical analysis of cerebrospinal fluid and blood samples, tissue homogenates, and animal models of multiple sclerosis. OS causes demyelination and neurodegeneration directly, by oxidation of lipids, proteins and DNA but also indirectly, by inducing a dysregulation of the immunity and favoring the state of proinflammatory response. In this review, we discuss the interrelated mechanisms of the impaired redox signaling, of which the most important are inflammation-induced production of free radicals by activated immune cells and growth factors, release of iron from myelin sheath during demyelination and mitochondrial dysfunction and consequent energy failure and impaired oxidative phosphorylation. Review also provides an overview of the interplay between inflammation, immunity and OS in MS. Finally, this review also points out new potential targets in MS regarding attenuation of OS and inflammatory response in MS.
\end{abstract}

\section{Key words}

Inflammation • Iron metabolism • Oxidative stress • Immunity • Autoimmune diseases • Antioxidants • Mitochondrial dysfunction

\section{Corresponding author}

D. Michaličková, Institute of Pharmacology, First Faculty of Medicine, Charles University in Prague and General University
Hospital in Prague, Albertov 4, 12800 Prague 2, Czech Republic. E-mail: marrtta@gmail.com

\section{Introduction}

Multiple sclerosis (MS) is an autoimmune neurological disease characterized by chronic inflammation of the central nervous system (CNS), leading to demyelination and axonal damage and resulting in a range of physical, mental or even psychiatric symptoms (van den Hoogen et al. 2017). The incidence of $\mathrm{MS}$ is on the rise: a global prevalence in 2013 was estimated to be at 2.3 million, constituting an increase of 0.2 million people from 5 years earlier (Ontaneda et al. 2017). About $85 \%$ of patients are diagnosed with relapsing-remitting (RR) MS, which is featured by alternating periods of neurological symptoms (relapses) and recovery (remissions). Approximately $70 \%$ develop secondary progressive MS 10-20 years after an initial RR course. Around $20 \%$ of patients are diagnosed with a primary progressive MS, which represents a progressive disease from onset (van den Hoogen et al. 2017, Ontaneda et al. 2017). Despite remarkable progress in the development of MS treatment in recent years, we are still far from finding a definitive drug for MS.

The etiology of MS is not fully understood, but it is believed to arise from a combination of genetic susceptibility, epigenetic and post-genomic events, and environmental factors such as viral pathogens, chemicals, smoking and diet (Grigoriadis et al. 2015, Penesová et al. 
2018). MS is characterized by auto-reactive Th1 and Th17 effector cells and other cells of the immune system that infiltrate the CNS and attack the myelin sheath (Diebold 2008). There is an emerging evidence that the pathogenesis of several neurodegenerative diseases, including $\mathrm{MS}$, involves the excessive generation of reactive oxygen species (ROS) and reactive nitrogen species (RNS) associated with mitochondrial dysfunction and energy deficit (Adamczyk et al. 2016, Fetisova et al. 2017, Mirshafiey et al. 2009, Neves Carvalho et al. 2017), indicated by the biochemical analysis of cerebrospinal fluid and blood samples, tissue homogenates, and animal models of MS (Haider 2015, Neves Carvalho et al. 2017, Ohl et al. 2016). Oxidative stress (OS) causes demyelination and neurodegeneration directly, by oxidation of lipids, proteins and DNA but also indirectly, by inducing a dysregulation of the immunity and favoring the state of pro-inflammatory response. In this review, we describe the mechanistic insights of the impaired redox signaling, as well as its complex interplay with immunity and inflammation in MS. We also point out potential targets of this delicate regulatory network, which could be utilized in the treatment of MS, as a supplement to the established treatments.

\section{Key players of redox milieu: reactive species and antioxidants}

Reactive species. ROS and RNS are highly reactive small molecules which are formed as natural byproducts of the normal aerobic metabolism and processes involved in response to pathogens. To become more stable, these species donate or receive another electron, which leads to the formation of new free radicals, resulting in a chain reaction. At low concentrations, ROS and RNS play an important role as regulatory mediators in signaling processes, such as growth and apoptosis at the cellular level and contribute to complex functions, including cognitive function, and immune function at the system level (Di Meo et al. 2016, Brieger et al. 2012). This state is defined as oxidative eustress (Sies et al. 2017). On the other hand, at high concentrations, in the state of oxidative distress, these molecules may cause OS and become harmful for living organisms by damaging important biomolecules, such as deoxyribonucleic acid (DNA), proteins and lipids (AbdulSalam et al. 2016, Di Meo et al. 2016, Michalickova et al. 2018, Sies et al. 2017). This happens when neutralization of ROS and RNS through antioxidant protective mechanisms is overwhelmed by their generation. It is important to emphasize that a ROS level causing damage to one cell type may be within the normal range for another cell type that possesses higher antioxidant capacity (AbdulSalam et al. 2016). This implies that the concentrations of reactive species govern the shift from their beneficial to deleterious effects, but the concentrations at which this shift happens are not generally known (Di Meo et al. 2016).

The free radical group includes compounds such as the superoxide anion radical $\left(\mathrm{O}_{2} \bullet^{-}\right)$, nitric oxide radical $(\mathrm{NO} \bullet)$, nitric dioxide radical $\left(\mathrm{NO}_{2} \bullet\right)$, hydroxyl radical $(\mathrm{OH} \bullet)$, alkoxyl $(\mathrm{RO} \bullet)$ and peroxyl $\left(\mathrm{RO}_{2} \bullet\right)$ radicals. Most typical non-radical reactive species relevant to biological systems are singlet oxygen $\left({ }^{1} \mathrm{O}_{2}\right)$, ozone $\left(\mathrm{O}_{3}\right)$, hydrogen peroxide $\left(\mathrm{H}_{2} \mathrm{O}_{2}\right)$, peroxynitrite $\left(\mathrm{ONO}_{2}{ }^{-}\right)$, hypochlorous acid ( $\mathrm{HOCl})$, organic peroxides and aldehydes. Reactive species generation is mediated through various pathways including the direct interaction between redox-active metals and oxygen species (e.g. Fenton reaction), peroxisomal oxidation of fatty acids, oxidation by cytochrome P450 enzymes and oxidative burst in several immune cells (Neves Carvalho et al. 2017). Two principle intracellular sources of ROS are mitochondria and ROS-producing enzymes, such as lipoxygenases (LOX), cyclooxygenases (COX), myeloperoxidase (MPO), xanthine oxidoreductase (XOR) systems, NO synthase (NOS) and nicotinamide adenine dinucleotide phosphate (NADPH) oxidase (NOX) (Adamczyk and Adamczyk-Sowa 2016, Brieger et al. 2012, Neves Carvalho et al. 2017). Mitochondria's primary function is to provide cells with energy, in the form of adenosine triphosphate (ATP), through reactions of oxidative phosphorylation (OxPhos). OxPhos is carried out by five multisubunit electron transport complexes (ETCs), designated complexes I-V. Electrons are transported from NADH to NADH coenzyme Q reductase (complex I) to coenzyme $\mathrm{Q}$, which also acquires electrons from succinate dehydrogenase (SDH/complex II). Coenzyme $\mathrm{Q}$ then transfers the electrons to cytochrome $\mathrm{C}$ oxidase (complex IV) via complex III (cytochrome bc1). Complex IV reduces molecular oxygen to water using these electrons (Paul et al. 2019). Beyond traditional roles of mitochondria in metabolism, mitochondria are also involved in ROS signaling, innate immunity and apoptosis (Shadel et al. 2015). ROS are formed as a by-product of OxPhos and up to $2 \%$ of the total cellular mitochondrial oxygen 
consumption may be related to the generation of ROS under normal physiological condition (Kim et al. 2015, Neves Carvalho et al. 2017). Apart from mitochondria, other organelles, such as peroxisomes and the endoplasmic reticulum (ER) are also important intracellular sources of ROS (Kim et al. 2015, Neves Carvalho et al. 2017). The roles of mitochondria and ROS-producing enzymes in the pathology of MS are in detail described in the section Redox signaling impairment in MS.

Antioxidants. Antioxidant protection consists of enzymatic and non-enzymatic antioxidants, which generally act in two ways: they prevent the formation of free radicals or react with the free radicals before their reaction with the essential biomolecules. In this way, they hinder or reduce the damage to important biological systems. Non-enzymatic antioxidants are low molecular weight compounds and are synthesized in the body (glutathione, bilirubin, uric acid, glutathione, ferritin, ceruloplasmin) or ingested through foods (vitamins A, C, E, carotenoids, $\alpha$-lipoic acid, flavonoids). Glutathione (GSH) is the main antioxidant in the brain, and plays a key role in the detoxification of reactive species (Carvalho et al. 2014). An important phenomenon in MS is an altered glutathione homeostasis, especially reduced glutathione reductase (GR) and glutathione peroxidase (GPx), although some researchers did not observe such abnormalities in their study subjects (Carvalho et al. 2014). Antioxidant enzymes catalyze the ROS neutralization reactions in the biological systems or the regeneration reaction, i.e. reduction of oxidized antioxidants. These enzymes include: superoxide dismutase (SOD), an enzyme that neutralizes the superoxide anion and represents the first line of defense against OS; glutathione peroxidase (GPX), which catalyzes the reduction of hydrogen peroxide and organic hydroperoxide in the presence of reduced GSH as an electron donor, while oxidized glutathione (GSSG) is formed at the same time; glutathione reductase (GR), which participates in regeneration of glutathione, i.e. reduction of oxidized glutathione in the presence of reduced nicotinamide-adenine dinucleotide phosphate (NADPH); catalase (CAT), an enzyme that has multiple functions, of which the most important is the elimination of hydrogen peroxide from the biological system by decomposition into water and oxygen (Adamczyk and Adamczyk-Sowa 2016, Michaličková et al. 2019).

The main regulator of the cellular antioxidant protective mechanisms is the transcription factor nuclear factor erythroid 2-related factor2 (Nrf2) (Liddell 2017, Neves Carvalho et al. 2017, Salim 2017, Barancik et al. 2016). Under normal physiological conditions, Nrf2 is sequestered in the cytosol by its negative regulator, kelchlike ECH-associated protein 1 (Keap1), and constitutively targeted for ubiquitination and proteasomal degradation (Liddell 2017, Zhang et al. 2004), Figure 1. This interaction keeps low basal expression of Nrf2 regulated genes. Oxidative or electrophilic challenges disrupt the complex between Nrf2 and Keap1, allowing Nrf2 to translocate to the nucleus, where it heterodimerises with small musculoaponeurotic fibrosarcoma (Maf) proteins (sMaf) and binds to antioxidant response elements (ARE) in the promoter region of target genes (Katsuoka et al. 2016, Liddell 2017, Neves Carvalho et al. 2017, Zhang et al. 2004). Nrf2 controls the expression of a various cytoprotective proteins, including the vast majority of antioxidant enzymes, such $\mathrm{NAD}(\mathrm{P}) \mathrm{H}$ quinone oxidoreductase 1 (NQO1) and heme oxygenase-1 (HO-1), peroxiredoxins, thioredoxins and enzymes that participate in the synthesis and metabolism of glutathione, such as y-glutamyl-cysteine synthetase (GCS), glutathione-Stransferases, GR, GPX (Lee et al. 2003, Liddell 2017, Neves Carvalho et al. 2017, Miao et al. 2019). In addition, Nrf2 also regulates the expression of antioxidant proteins like ferritin; several genes involved in autophagy, including SQSTM1 encoding p62 protein, enzymes with anti-inflammatory activity such as leukotriene B4 dehydrogenase; and proteins involved in protein quality control and degradation like heat-shock protein 70 (Hsp70) and subunits of the proteasome (Baird et al. 2011, Kwak et al. 2003, Neves Carvalho et al. 2017, Pajares et al. 2016). Emerging number of studies indicates a dysregulation of Nrf2 system in brains of individuals suffering from neurodegenerative diseases, such as Alzheimer's disease, parkinsonism and amyotrophic lateral sclerosis (Liddell 2017, Jiang et al. 2018). A decrease in a transcription factor complex containing Nrf2 in human samples of MS grey matter has been reported, and this correlated with reduced expression of OxPhos genes and increased oxidative damage (Pandit et al. 2009). Moreover, Nrf2-deficient mice in the model of experimental autoimmune encephalomyelitis (EAE), the most used pre-clinical MS model, expressed a more severe phenotype and augmented microglial activation (Johnson et al. 2009, Lassmann et al. 2016). Importantly, it appears that Nrf2 expression level is cell-type specific. Higher expression of $\mathrm{Nrf} 2$ is found in astrocytes and infiltrating 
macrophages in active lesions (van Horssen et al. 2010), and in oligodendrocytes (OL) at lesion edges (LichtMayer et al. 2015). Nrf2 expression is however lower in neurons, even when surrounded by Nrf2-positive glia (van Horssen et al. 2010) and this may account for a limited capacity of neurons to cope with OS.

Nrf2 induction represents a promising intervention for the restoration of the cellular antioxidative response and attenuation of inflammation in MS. Currently, there is one drug approved by EMA for the treatment of RR MS, which activates Nrf2: it is dimethyl fumarate (DMF; trade name: Tecfidera). Up to date, there have been multiple preclinical studies and also several clinical trials evaluating potential of other Nrf2 activators in the treatment of MS. Noteworthy, these molecules also display anti-inflammatory effects through other mechanisms in addition to Nrf2 activation, such as SIRT1 activation, NF-kB, c-Jun N-terminal kinase (p-JNK), protein kinase RNA-like endoplasmic reticulum kinase (p-ERK), and phospho-p38 members of the mitogen-activated protein kinase (MAPK) pathway attenuation (Adamczyk and Adamczyk-Sowa 2016, Miller et al. 2019, Saso et al. 2014). Based on preclinical studies, compounds which seem to have therapeutic potential are: sulforaphane, curcumin, melatonin, resveratrol, several flavonoids, such as quercetin, EGCG, naringenin (Long et al. 2018, Mohajeri et al. 2015, Li et al. 2013, Fonseca-Kelly et al. 2012, Muthian et al. 2004, Semnani et al. 2017). Results from the clinical trials are however less conclusive on this topic. Currently, there are several clinical trials evaluating curcumin, melatonin, and EGCG. Two clinical trials (NCT03150966 and NCT01514370) examining curcumin efficacy in the patients with MS are still ongoing, and the results have not been published. Moreover, six clinical studies have been registered (NCT00525668, NCT02011451, NCT00799890, NCT00836719, NCT01451723, and NCT01417312) and three have posted the results. Majority of the clinical studies have examined the safety and the neuroprotective potential of EGCG by determination of levels of $\mathrm{N}$-acetyl aspartate (NAA, which is utilized to assess the number and metabolism of neurons). The results of these studies are mixed; two small-scale clinical studies have shown no improvement in NAA level in the brain, with an enhancement of hepatotoxicity after 6-month supplementation with $800 \mathrm{mg}$ EGCG extract (Lovera et al. 2015), whereas the other study (12 weeks, $600 \mathrm{mg}$ EGCG extract) has shown some metabolic effects (decreased postprandial carbo-hydrates oxidation, adipose tissue perfusion, and glucose supply, and shift to a higher and more stable carbohydrate during exercise), but only in men and not in women (Mähler et al. 2015). Another study examining a single high dose of EGCG $(750 \mathrm{mg})$ in healthy subjects has reported no impairment of COMT (Lorenz et al. 2014). Moreover, there have been several human studies evaluating melatonin in MS patients already treated with disease-modifying therapies (DMT, mitoxantrone, interferon beta, glatiramer acetate). Three registered studies are currently in progress or are finished, but did not post the results: NCT03150966 (phase II), NCT03498131 (phase I), NCT01279876 (phase II). No clinical studies have assessed the Keap1/Nrf2/ARE pathway expression in treated patients. Most of the studies did not include doubled blind randomized design, but rather healthy controls as a comparison to the melatonin-treated group of MS patients. Melatonin administration has improved several markers of OS and antioxidant protection (it has increased SOD and decreased MDA in serum) and inflammation RR MS patients, which in some cases coincided with the improvement in the quality of life of these patients. Melatonin was administered in wide range of doses (2 to $25 \mathrm{mg}$ ) during the wide range of treatment duration (30 days to 12 months), so the future trials will have to provide information on the safe and effective dose. Details of therapeutic potential of these compounds are out of the scope of this review, but interested readers are referred to (Dinkova-Kostova et al. 2015, Dinkova-Kostova et al. 2018, Neves Carvalho et al. 2017, Shokeir et al. 2015).

\section{Redox signaling impairment in MS}

The central nervous system (CNS) is especially vulnerable to OS due to high oxygen utilization, suboptimal antioxidant defense mechanisms compared to peripheral tissues and high abundance of polyunsaturated fatty acids which making the CNS particularly susceptible to lipid peroxidation (Neves Carvalho et al. 2017, Paul and Snyder 2019). Moreover, brain tissue contains significant amounts of metals ions, such as iron $(\mathrm{Fe})$, copper $(\mathrm{Cu})$, manganese $(\mathrm{Mn})$, and zinc $(\mathrm{Zn})$ which contribute to the generation of the highly toxic hydroxyl radicals (Sheykhansari et al. 2018). Finally, brain areas rich in catecholamines are particularly susceptible to OS, since catecholamines cause free radicals generation by auto-oxidation or through metabolism by monoamine 
oxidases (Neves Carvalho et al. 2017). However, the susceptibility to OS varies between different cells of the CNS, such as neurons or different glial cells. The level of energy demand, the dominant pathway of energy production, expression of antioxidant protective mechanisms, susceptibility for apoptosis induction and potential of handling the overload of divalent metal cations determine vulnerability of cells to OS (Lassmann and van Horssen 2016, Stys 2005). Neurons and OL are the cells most vulnerable to OS, while astrocytes and microglia appear to be more resistant (Lassmann and van Horssen 2016). Neurons have a limited capacity to counteract OS due to low expression of the main regulator of antioxidative defense Nrf2 (van Horssen et al. 2010) and a regulator of crucial mitochondrial biogenesis and antioxidant mechanisms, peroxisome proliferator-activated receptor gamma coactivator 1-alpha (PGC-1 $\alpha$ ) (Witte et al. 2013). High lipid content and iron accumulation might be responsible for high vulnerability to OS of myelin sheaths and OL to OS. On the other hand, astrocytes are better equipped with antioxidant protection and have a low tendency to iron accumulation, probably due to extensive expression of iron exporters (Zarruk et al. 2015, Lassmann and van Horssen 2016, Nijland et al. 2014). Finally, microglia and macrophages, as the main cellular sources of ROS and RNS, have a considerable amount of antioxidant molecules and seem to be well protected from OS (van Horssen et al. 2008), however, it should be mentioned that augmented iron accumulation happens in microglia in the ageing human brain (Hametner et al. 2013).

The main interrelated mechanisms responsible for generation of reactive oxygen and nitrogen species and oxidative injury in patients with MS are:

A) inflammation-induced production of free radicals by activated immune cells and growth factors,

B) release of iron from myelin sheath during demyelination and

C) mitochondrial dysfunction and consequent energy failure and impaired oxidative phosphorylation (Haider 2015).

Importantly, oxidative injury has been described in active and low grade, acute and chronic inflammatory lesions, in the white and gray matter, as well as in RR and progressive MS, but the mechanisms leading to oxidative injury in these conditions are not the same (Lassmann and van Horssen 2016, Mahad et al. 2015, Witte et al. 2014). Initial acute inflammatory MS lesions are predominantly associated with inflammation and oxidative burst activation of microglia, which lead to severe mitochondrial dysfunction, whereas the progressive stages are mainly characterized by amplification mechanisms, such as chronic mitochondrial dysfunction or iron accumulation in the brain and its liberation in demyelinating lesions (Lassmann and van Horssen 2016). These mechanisms are described in the following section and presented in Figure 2.

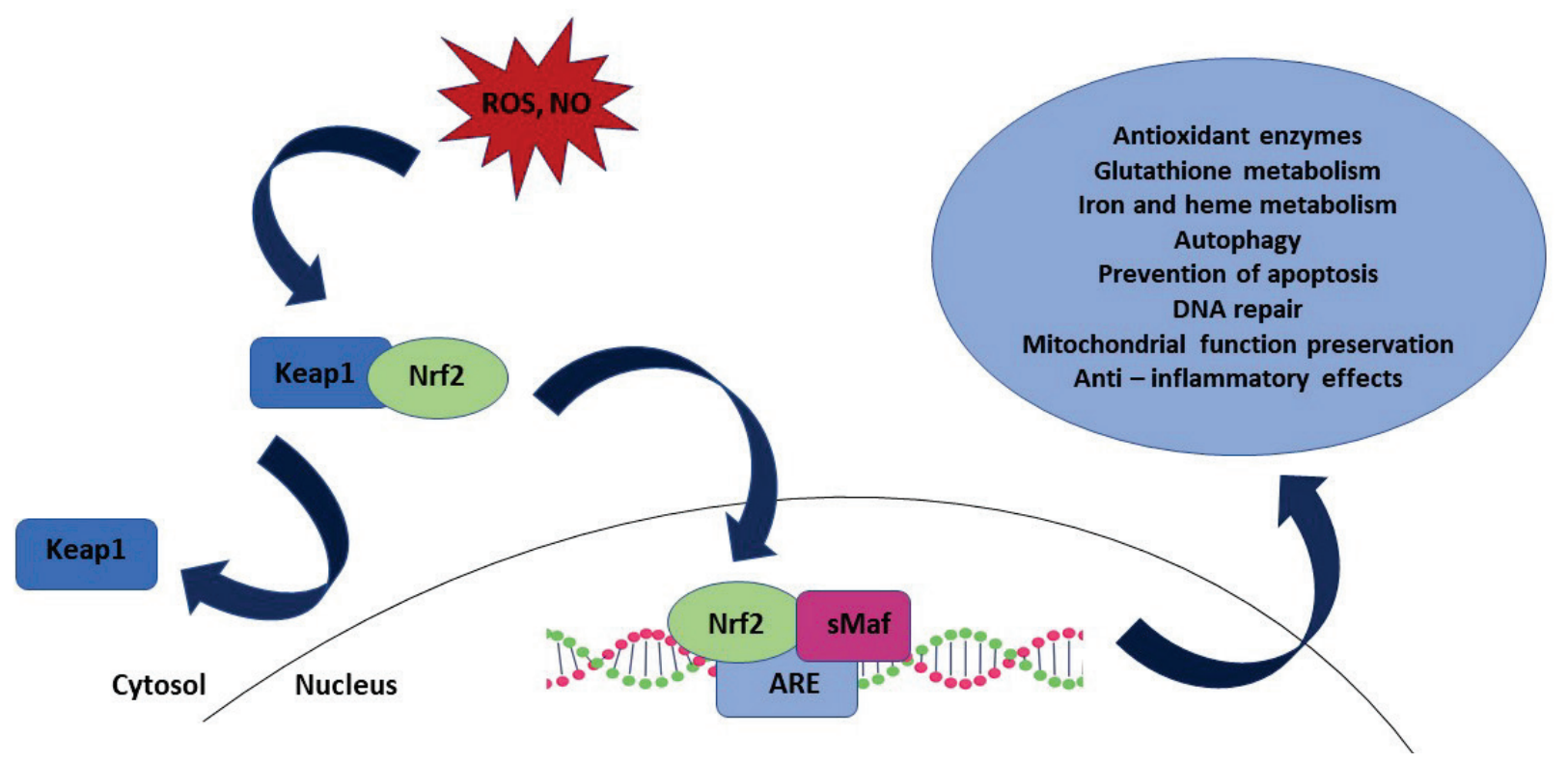

Fig. 1. Cellular pathways driven by Nrf2 target genes. Oxidative or electrophilic challenges disrupt the complex between Nrf2 and Keap1 (kelch-like ECH-associated protein 1), allowing Nrf2 to translocate to the nucleus, where it heterodimerises with small musculoaponeurotic fibrosarcoma (sMaf) proteins and binds to antioxidant response elements (ARE) in the promoter region of target genes. This results in a cascade of reactions with ultimate anti-inflammatory and antioxidant effects. 


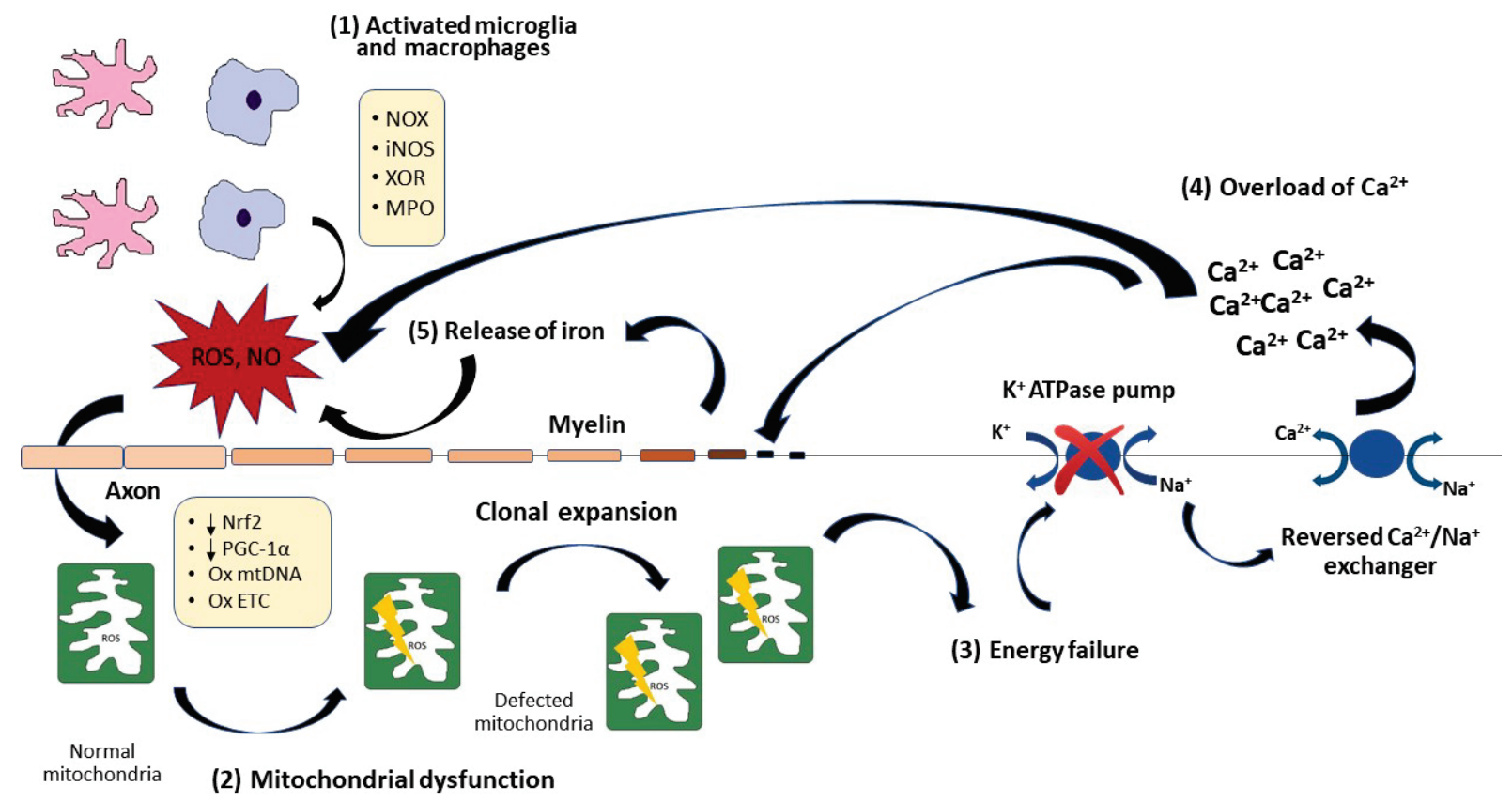

Fig. 2. Mechanisms of oxidative injury in multiple sclerosis. The time sequence and interrelation of redox events in MS are different in relapsing and progressive MS, acute and chronic MS, but also different in different stages of the disease and different patients. Therefore, this figure does not illustrate a timeline from events shown in (1) to those in (5). (1) The initial source of oxidative injury in MS is an oxidative burst activation of macrophages and microglia. The enzymes responsible for the oxidative burst are NADPH oxidase (NOX), iNOS, XOR and myeloperoxidase (MPO). (2) Reactive species released during inflammatory response from the activated microglia and macrophages damage the components of the respiratory chain, endangering energy metabolism and adenosine triphosphate (ATP) production. In the conditions of inefficient oxidative phosphorylation (OxPhos), respiratory chain itself also becomes an important source of OS. In addition, reactive species also damage mitochondrial DNA (mtDNA), causing mtDNA mutations and deletions. During time, defective mitochondria are amplified by the clonal expansion in neurons. (3) A combination of these events eventually results in energy failure and decreased ATP production. At certain point, mitochondrial dysfunction accumulates to such an extent that ATP production becomes insufficient for $\mathrm{Na}^{+} / \mathrm{K}^{+}$ATPase to eliminate excess $\mathrm{Na}^{+}$from the axons. The increasing intraaxonal $\mathrm{Na}^{+}$level leads to the reversal of the axolemmal $\mathrm{Na}^{+} / \mathrm{Ca}^{2+}$ exchanger, which in normal physiological conditions pumps $\mathrm{Na}^{+}$in and $\mathrm{Ca}^{2+}$ out of the axon. (4) This leads to elevation of axonal $\mathrm{Ca}^{2+}$ concentration, which triggers a cascade of several deleterious events, eventually causing disruption of intra-axonal mitochondria and increased ROS production, and finally axonal degeneration. (5) Iron is physiologically stored within the myelin sheets; however, demyelination triggers its release into the extracellular space. Subsequently, it undergoes conversion to the divalent ferrous form, which can increase the toxicity of ROS. In Fenton reaction, $\mathrm{Fe}^{2+}$ is oxidized to Fe ${ }^{3+}$, while hydrogen peroxide is converted to highly toxic hydroxyl radical and hydroxyl anion. Liberated iron is taken up by macrophages and microglia, which release and deposit iron during phagocytosis of damaged neurons. High iron load may even induce cell death, after which iron is further released initiating a second wave of OS and causing an amplification of oxidative injury.

\section{Inflammation}

Key features of MS, chronic OS and dysregulation of inflammatory response, are closely related. Active inflammation and disruption of the blood-brain barrier (BBB) have been detected in the brains of patients with MS as gadolinium enhancing magnetic resonance imaging lesions (Filippi et al. 2019, Haider 2015). Highly pro-inflammatory and autoreactive leukocytes (especially T-helper 1 (Th1) and T-helper 17 (Th17) cells) infiltrate into CNS, where they produce IFN- $\gamma$ and IL-17A. The inflammatory reaction that follows further increases the permeability of the BBB and recruits other immune cells, such as B cells and monocytes, to the CNS (AdamczykSowa et al. 2016, van den Hoogen et al. 2017). These processes are paralleled by continuous activation of resident macrophages/microglia, which produce pro- inflammatory cytokines and chemokines, as well as reactive oxidants, leading to OL death, axon damage, and ultimately neuronal loss. These immune cells in active MS lesions express enzymes involved in the oxidative burst, such as NADPH oxidase (NOX), iNOS, XOR and myeloperoxidase (MPO) (Fischer et al. 2012, Gray et al. 2008b). The initial source of oxidative injury in MS is an oxidative burst activation of macrophages and microglia. Another important source of reactive species during inflammation are the several receptors of growth factors, such as epidermal growth factor receptor (EGFR) (Meng et al. 2007) and platelet derived growth factor receptor (PDGFR) (Yang et al. 2016).

The main source of ROS in microglia is the family of NOX enzymes (for an excellent review on the role of NOX enzymes in the MS (Ma et al. 2017)). Pro-inflammatory cytokines, primarily tumor necrosis 
factor alpha (TNF- $\alpha)$ and IL1- $\beta$, represent the major inducers of both phagocytic and non-phagocytic NOX (Valacchi et al. 2018). NOX family of enzymes is responsible for superoxide production through the electron transfer from NADPH to oxygen (Kim et al. 2015). To date, seven NOX isoforms have been identified in mammalian cells, including NOX1 to NOX5 and dual oxidases (Duox1 and Duox2) (Ma et al. 2017). Each NOX isoform has a distinctive function, cellular localization, type of generated ROS and regulation (Ma et al. 2017, Neves Carvalho et al. 2017). NOX1, NOX2 and NOX4 are expressed in brain. NOX2 and NOX1 were reported to be upregulated in activated microglia in active demyelinating and chronic MS lesions in human MS patient brain tissue (Fischer et al. 2012). Additionally, NOX2 was found to be upregulated in activated microglia in pre-active MS lesions found throughout normal appearing white matter of MS patients. Since NOX is the only enzyme family that has an exclusive function to form ROS, its regulation might be particularly important in the context of MS pathology. Therefore, NOX, especially NOX2, represents an attractive therapeutic target in MS. NOX2 deletion in the model of EAE ameliorated OL loss, and reduced microglia reactivity (Li et al. 2011). Furthermore, NOX2 inhibitors, such as apocynin, celastrol, dextromethorphan and dietary phytol, have been reported to ameliorate clinical scores in EAE (Abdin et al. 2014, Blum et al. 2018, Choi et al. 2015, Yang et al. 2017, Chechneva et al. 2011). No clinical trials evaluating these compounds in clinical trials have been reported.

Another enzyme in phagocytes accountable for oxidative burst is MPO, a heme peroxidase responsible for the production of hypochlorous acid $(\mathrm{HOCl})$ from hydrogen peroxide $\left(\mathrm{H}_{2} \mathrm{O}_{2}\right)$ and chloride anion $\left(\mathrm{Cl}^{-}\right)$ (Neves Carvalho et al. 2017). This enzyme was found to be predominantly expressed by macrophages and activated microglia within and in the vicinity of MS plaques in white matter lesions, but also in a subtype of microglia surrounding cortical lesions (Gray et al. 2008a, van der Veen et al. 2009). In the model of EAE, increased MPO activity in the CNS has been found (Forghani et al. 2012, Sajad et al. 2009). Interestingly, administration of non-toxic MPO inhibitor $\mathrm{N}$-acetyl lysyltyrosylcysteine amide for 5 days starting at the peak of disease significantly attenuated EAE disease severity, reduced myeloid cell numbers and permeability of the BBB (Zhang et al. 2016).

Xanthine dehydrogenase (XDH) and xanthine oxidase (XO) are interconvertible forms of XOR, a system involved in the conversion of hypoxanthine to xanthine and the conversion of xanthine to uric acid (UA) (Meneshian et al. 2002). Apart from its role in the purine metabolism, XOR also plays a pathophysiological roles through the generation of various types of ROS, including superoxide, hydrogen peroxide and NO (Meneshian and Bulkley 2002). Febuxostat, an inhibitor of XOR, was found to attenuate axonal loss and ameliorated both RR and secondary progressive EAE by preventing neurodegeneration in mice (Honorat et al. 2013, Honorat et al. 2017).

An additional hallmark of microglial overactivation is the high production of $\mathrm{NO}$, however it should be stressed that NO production is much more relevant in rodents than in humans (Rojo et al. 2014, Genc et al. 2006). NOS is responsible for synthesis of NO in mammals though catalysis of a reaction of L-arginine and dioxygen that proceeds at the expense of NADPH oxidation. There are three major isoforms of NOS: neuronal NOS (nNOS), endothelial NOS (eNOS) and inducible NOS (iNOS). nNOS and eNOS are constitutively expressed and require calcium and calmodulin for activation, whereas iNOS is largely calcium independent and induced in inflammatory conditions ( $\mathrm{Li}$ et al. 2011). NO has a dual, both physiologic and pathophysiologic role in the CNS. NO acts as a messenger molecule between neurons, astrocytes and blood vessels (Bicker, 2001). NO has a protective role in the CNS, as it modulates signaling pathways which are crucial for survival and differentiation of neurons, such as cAMP-responsive element-binding protein (CREB) and extracellular signal-regulated kinase (ERK) (Ockelford et al. 2016). Pathologic role in the CNS is displayed mainly through its reactive product peroxynitrite $\left(\mathrm{ONOO}^{-}\right)$, which is formed in the presence of superoxide ion and hypoxic conditions (Haider 2015, Lan et al. 2017). OL and oligodendroglial precursor cells (OPCs) are highly susceptible to $\mathrm{NO} / \mathrm{ONOO}^{-}$. $\mathrm{NO} / \mathrm{ONOO}^{-}$cause $\mathrm{OL}$ mitochondrial dysfunction via inhibition of the respiratory chain, oxidation and disruption of mitochondrial DNA (mtDNA), and the impairment of the mitochondrial membrane (Jack et al. 2007, Mander et al. 2005). This leads to damage to the myelin structure, but also to impaired remyelination of axons (Pang et al. 2010). Recently, oxidoreductase glutaredoxin 2 (Grx2) was found to inhibit $\mathrm{ONOO}^{-}$ formation by conversion of NO to dinitrosyldiglutathionyl-iron-complexes and this was associated 
with prevention of myelin damage in the EAE model (Lepka et al. 2017). Interestingly, glutaredoxin 2-mediated protection was not found to be related to its enzymatic activity as oxidoreductase, but to the disassembly of its coordinated iron-sulfur cluster using GSH as non-protein ligand (Lepka et al. 2017). This indicates that boosting Grx2 or other GSH coordinated iron-sulfur clusters leads to prevention of toxic $\mathrm{ONOO}^{-}$ generation and consequently leads to prevention of neuroinflammation. Another GSH-coordinated ironsulfur cluster, $\left[\left[\mathrm{Fe}_{2} \mathrm{~S}_{2}\right]^{2+}\left(\mathrm{GS}^{-}\right)_{4}\right]^{2-}$ complex, that might be feasible in the condition of MS has been recently characterized (Qi et al. 2012).

Moreover, inhibition of iNOS could be a potential target in the treatment of MS (for detailed review see Lan et al. 2017). Up to date, several NOS inhibitors have been developed and examined in preclinical and clinical studies for conditions other than MS (Tejero et al. 2018). Selective iNOS inhibitors GW273629 and GW274150 have shown to be ineffective in clinical trials for migraine (NCT00242866; NCT00319137) (Høivik et al. 2010, van der Schueren et al. 2009), but they have not been tested in EAE and MS. The pterin 4-amino-tetrahydrobiopterin (VAS203) is a non-selective NOS inhibitor that has shown efficacy in the treatment of traumatic brain injury and has been used in phase II clinical trial (NCT02012582) (Stover et al. 2014). Additionally, edaravone, an inhibitor of iNOS, was shown to ameliorate the clinical severity of EAE and to reduce lymphocytes infiltration of lymphocytes to CNS (Moriya et al. 2008). This drug is currently approved for the treatment of amyotrophic lateral sclerosis (ALS) in the U. S. and Japan and additionally for the treatment of acute-phase cerebral infarction after two successful clinical trials (NCT00330681, NCT01492686).

\section{Mitochondrial dysfunction}

In addition to their primary function to provide cells with the energy, through the reactions of oxidative phosphorylation (OxPhos), mitochondria have a central role in the redox homeostasis, and the immune response regulation (Min et al. 2018). Mitochondrial dysfunction plays a central role in redox imbalance in MS (for comprehensive review see (Witte et al. 2014, Campbell et al. 2014)). Mitochondria uniquely possess residual mtDNA, which is responsible for regulation of 1200 proteins, including those that control the activity of
OxPhos (Min et al. 2018). mtDNA, and generally mitochondrial biogenesis and homeostasis are under tight control of the nuclear DNA. Mitochondrial genome is smaller than the nuclear one, has only one DNA polymerase, and also lacks protective histones, which makes it highly susceptible to OS. ROS released during inflammatory response from the activated microglia and macrophages damage the components of the respiratory chain, through either functional inhibition or increased breakdown of the concerned proteins (Lassmann and van Horssen 2016). Also NO competes with oxygen for binding sites of respiratory chain (Mander et al. 2005). In return, inefficient OxPhos further increases generation of reactive species, leading to a vicious circle of mitochondrial dysfunction and OS (Haider 2015). Namely, in normal physiological conditions, only $1-2 \%$ of the electrons escape the OxPhos to the mitochondrial matrix (Halliwell et al. 1984), where they produce superoxide through the reaction with molecular oxygen (Cadenas et al. 1977). However, when ATP production is jeopardized, mitochondrial superoxide production is enhanced (Lassmann and van Horssen 2016). Reactive species released during inflammatory response also damage mtDNA, causing mtDNA mutations and deletions (Campbell et al. 2011), which ultimately endanger OxPhos function, energy metabolism and ATP production (Lassmann and van Horssen 2016, Mahad et al. 2008).

Over time and with cell aging, abnormal mitochondria are amplified in neuronal cell bodies through clonal expansion of mtDNA deletions and depleted transcripts (Campbell et al. 2014, Witte et al. 2014). Currently, it is not known why mitochondria with mutated mtDNA undergo clonal expansion (Haider 2015). Increased number of defected mitochondria eventually leads to progressive mitochondrial dysfunction in neurons, which is especially featured in the progressive MS (Frischer et al. 2009, Witte et al. 2014). At certain point, mitochondrial dysfunction accumulates to such an extent that ATP production becomes insufficient for $\mathrm{Na}^{+} / \mathrm{K}^{+}$ATPase to eliminate excess $\mathrm{Na}^{+}$from the axons (Campbell et al. 2014, Lassmann and van Horssen 2016, Witte et al. 2014). The increasing intra-axonal $\mathrm{Na}^{+}$level leads to the reversal of the axolemmal $\mathrm{Na}^{+} / \mathrm{Ca}^{2+}$ exchanger, which in normal physiological conditions pumps $\mathrm{Na}^{+}$in and $\mathrm{Ca}^{2+}$ out of the axon. Consequently, this leads to elevation of axonal $\mathrm{Ca}^{2+}$ concentration, which triggers a cascade of several deleterious events, eventually causing disruption of intra-axonal 
mitochondria and increased ROS production, and finally axonal degeneration (Campbell et al. 2014, Lassmann and van Horssen 2016, Witte et al. 2014). Apart from energy deficiency, mitochondrial dysfunction can also give rise to neurodegeneration by other mechanisms (Lassmann and van Horssen 2016). For example, release of cytochrome $\mathrm{C}$ and apoptosis inducing factor from mitochondrial stores induces apoptosis (Ow et al. 2008). This finding is important considering that apoptotic $\mathrm{OL}$ death can be seen as a primary mechanism of demyelination in MS lesions (Lassmann and van Horssen 2016).

Furthermore, decreased expression of PGC- $1 \alpha$, an important regulator of mitochondrial proteins and biogenesis, and the main regulator of energy metabolism, has been found in patients with progressive MS, even in normal appearing white matter (NAWM) (Nijland et al. 2014). NAWM is the tissue surrounding white matter inflammatory lesions and without any marked changes in myelin proteins expression. Decreased PGC- $1 \alpha$ expression seems to be an important contributor of defected energy metabolism (Nijland et al. 2014, Witte et al. 2014). However, it is still unknown what is the cause of this phenomenon, but it was hypothesized that continuous microglial inflammatory response might be crucial (Witte et al. 2014, Witte et al. 2013). Up to date, resveratrol (previously mentioned as a Nrf2 inducer) and several compounds belonging to group of thiazolidines have been reported to enhance PGC- $1 \alpha$ expression which has been associated with decrease in neuronal loss and improved axonal density in the SC (Shindler et al. 2010, Hondares et al. 2006). These results have to be corroborated in clinical trials.

Recently, multiparametric imaging technique for analysis of mitochondrial redox signals, assessing mitochondrial shape, redox state, $\mathrm{pH}$, calcium levels and membrane potential has been developed (Breckwoldt et al. 2014). This technique has revealed that there are two kinds of axonal mitochondrial "contractions" (fluctuations in redox signals manifested through changes in mitochondrial shape, $\mathrm{pH}$ of mitochondrial matrix, calcium levels and membrane potential): transient and permanent. Transient fluctuations represent a mitochondrial response to physiological stress and are reversible, whereas permanent, which can become irreversible, are triggered by more severe axonal injuries, such as axotomy (Breckwoldt et al. 2016, Breckwoldt et al. 2014). Axotomy-induced permanent contractions were accompanied by transition pore opening and could not be prevented by ROS scavenging. However, transient contraction could be prevented by a class of mitochondria-targeted antioxidants (MTA). This groups includes mitoquinone (MitoQ), mitotocopherol (MitoVitE), skQ1, which are lipophilic cations that can pass through all biological membranes and accumulate within mitochondria more easily than their non-targeted parent antioxidants. Many preclinical studies showed promising antioxidant and anti-inflammatory effects in EAE model and currently, MitoQ is in Phase 1 clinical trial for fatigue in MS (NCT03166800). Details on the therapeutic potential of MTA are out of the scope of this review, but interested reviewers are referred to a comprehensive review (Fetisova et al. 2017).

\section{Iron deposition}

Dysregulation of iron metabolism in the brain is another mechanism contributing to OS within the pathogenesis of MS. For detailed review readers are referred to (Stephenson et al. 2014) and (Dusek et al. 2016). Excessive iron concentration was revealed in the white matter lesions and deep gray matter structures (Haider 2015). Highest iron concentration was found in basal ganglia and was associated with increased disability and cognitive dysfunction (Schmalbrock et al. 2016, Hallgren et al. 1958). Conversely, reduced iron levels were revealed in the normal-appearing white matter (NAWM) and remyelinated plaques (Hametner et al. 2013), suggesting that the iron dysregulation associated with MS is not purely global iron accumulation, but rather a redistribution of iron levels between different areas of the brain (Stephenson et al. 2014). In the biological systems, iron can be found in the ferrous $\left(\mathrm{Fe}^{2+}\right)$ and ferric $\left(\mathrm{Fe}^{3+}\right)$ states (Stephenson et al. 2014). In the human brain, iron is predominantly stored in the nontoxic trivalent $\left(\mathrm{Fe}^{3+}\right)$ form by ferritin in the myelin sheets, OLs and microglia (Haider 2015, Hulet et al. 1999). It accumulates physiologically with age, plateauing at 40-50 years, depending on the anatomical area (Haider 2015, Hallgren and Sourander 1958). During myelin breakdown and subsequent phagocytosis of myelin debris which occur at active MS lesions, iron is liberated into the extracellular space. Subsequently, it undergoes conversion to the divalent ferrous form, which can increase the toxicity of ROS (Mahad et al. 2015). In Fenton reaction, $\mathrm{Fe}^{2+}$ is oxidized to $\mathrm{Fe}^{3+}$, while hydrogen peroxide $\left(\mathrm{H}_{2} \mathrm{O}_{2}\right)$ is converted to highly toxic hydroxyl radical $(\cdot \mathrm{OH})$ and hydroxyl anion $\left(\mathrm{OH}^{-}\right)$. Liberated iron is taken up by macrophages and microglia, which release 
and deposit iron during phagocytosis of damaged neurons (Neher et al. 2011). High iron load may even induce cell death, after which iron is further released initiating a second wave of OS. Additionally, activated macrophages release NO that can promote other iron release from ferritin (Neher et al. 2011). Finally, iron might also activate immune cells and affect their polarization (Stephenson et al. 2014). Diverse stimuli can shape macrophages and microglia respond to various stimuli by becoming polarized towards different phenotypes (Stephenson et al. 2014). The M1 phenotype of activated macrophages is characterized by proinflammatory immune response and promotion of type 1 T-helper cells differentiation. On the contrary, the M2 phenotype is related to increased debris clearance and is considered regulatory and anti-inflammatory (Durafourt et al. 2012, Stephenson et al. 2014). Iron overload in macrophages promotes a pro-inflammatory M1 activation state (Durafourt et al. 2012), leading to generation of reactive species.

Although preclinical studies showed that chelators ameliorate clinical severity in EAE, clinical studies had rather inconclusive and even disappointing results (Dusek et al. 2016). More research in the complex topic of iron metabolism in MS is needed before iron chelation can be recommended as beneficial therapeutic strategy.

\section{Interplay between OS and inflammation: the state of "oxinflammation"}

Recently, the term "oxinflammation" has been proposed to depict the vicious circle of chronic inflammation and OS, which is the hallmark of many chronic diseases, including MS (Valacchi et al. 2018). As previously described, pro-inflammatory mediators enhance generation of reactive species, but it is important to emphasize that reactive species in return also favor the progression of inflammation. While in a redox balance state an increase in the reactive species level stimulates the endogenous antioxidant defense, during chronic impaired redox homeostasis, intracellular signaling pathways are altered and result in a loss of the regulation of signals transduction by the cells (SolleiroVillavicencio et al. 2018). This occurs because of the activation of the phosphorylation pathways and inhibition of dephosphorylation enzymes (Solleiro-Villavicencio and Rivas-Arancibia 2018). OS causes a dysregulation of immune response and favors the state of pro- inflammatory response. Moreover, reactive species have also been associated with the activity of matrix metalloproteinases (MMPs), proteins that have an important role in T cells trafficking into the CNS (Leppert et al. 1995). Reactive species can activate cells of immune system to induce protein kinase cascade (PKC, MAPKs etc.) and redox-sensitive transcription factors, most importantly AP-1 and nuclear factor kappalight chain-enhancer of activated $\mathrm{B}$ cells $(\mathrm{NF}-\mathrm{\kappa} B$ ) (Valacchi et al. 2018). NF- $\mathrm{KB}$ is a transcription factor, primarily involved in the modulation of inflammatory/ immune responses, cell apoptosis and cellular growth. Upon activation, NF- $\mathrm{kB}$ upregulates the expression of many genes involved in MS and EAE pathogenesis, including TNF- $\alpha$, iNOS, IL- $\alpha / \beta$, vascular adhesion molecules 1 and various growth factors (Winyard et al. 1996).

NOX2 enzymes are an excellent example of the interconnection between redox processes and inflammation in MS. As previously mentioned, NOX enzymes are the most important source of reactive species during acute inflammation response and the only enzyme family with an exclusive function to form ROS. Activation of NOX2 by pro-inflammatory mediators, such as TNF- $\alpha$ and IL-1 $\beta$, is followed by formation of ROS, which in turn elicit cascade of inflammatory events, and cause a formation of a number of pro-inflammatory mediators including those involved in the activation of NOX2 (Valacchi et al. 2018). The presence of a specific protein, termed negative regulator of ROS (NRROS), has been described (Noubade et al. 2014). This biomolecule directly interacts with the NADPH oxidase complex and facilitates the degradation of NOX1 and NOX2 proteins, and consequently limits the ROS production from phagocytes during inflammation (Noubade et al. 2014). NRROS deficient phagocytes produce increased ROS upon inflammatory challenges: for example, mice lacking NRROS in the phagocytes exhibited elevated bactericidal activity against Escherichia coli and Listeria monocytogenes. On the other hand, these mice developed severe EAE due to excessive oxidative tissue damage in the CNS. Interestingly, NRROS expression in phagocytes was found to be repressed by inflammatory signals. Therefore, further understanding of this pathway may represent a novel therapeutic target for diminishing ROS production in various diseases, including MS.

Inflammasomes are another good example of mutual connection between OS and inflammation in MS. Inflammasomes are multiprotein complexes which detect 
pathogenic microorganisms and sterile stressors, and increase maturation of the pro-inflammatory cytokines IL-1 $\beta$ and IL-18 or lead to cell death (Singhal et al. 2014). Inflammasomes can be found in the cytosol of several types of cells, including immune cells (such as T cells, B cells, dendritic cells, and macrophages), neural cells, microglia, and astrocytes, as well as pulmonary endothelial cells (Lang et al. 2018). The role of NLRP3 (nucleotide-binding oligomerization domain-like receptor containing pyrin domain 3) inflammasome has been best described in the pathogenesis of MS. Two signals are required for NLRP3 inflammasome activation: a "priming" step that involves NF- $\mathrm{B}$ signaling, which is followed by activation of pro-caspase-1, a critical factor for maturation of cytokines (Singhal et al. 2014). Inflammasomes can also be activated experimentally by mitochondrial reactive species by the inhibitors of the respiratory chain, rotenone and antimycin (Bulua et al. 2011). Scavenging mitochondrial superoxide suppresses NLRP3 activation, whereas NLRP3 agonists elevate generation of reactive species (Zhou et al. 2011, Abais et al. 2015). However, the mechanisms of NLRP3 activation by ROS have not been elucidated (Fetisova et al. 2017).

It has been proven that the activation and differentiation of $\mathrm{T}$ lymphocytes, crucial drivers of MS development course, depends on redox conditions of the microenvironment (Solleiro-Villavicencio and RivasArancibia 2018, Ohl et al. 2016). Actually, ROS represent the third activation signal for $\mathrm{T}$ lymphocytes. Both amount and type of reactive species exert different effects upon T cells, which also show the ability to convert from one to another cell lineage under certain inflammatory conditions (Solleiro-Villavicencio and Rivas-Arancibia 2018). Generally, chronic OS promotes differentiation toward pro-inflammatory phenotypes such as Th1 and Th17. For example, NOX-deficient mice showed a skewed Th17 response, while NOX-intact mice exhibited cytokine profile characteristic for Th1 response (Hubert et al. 2010). In another study, mitochondrial inhibitors of ROS $\mathrm{N}$-acetylcysteine and mitoquinone reduced differentiation to Th17 phenotype in a mouse model of IEX-1 gene deficiency (this deficiency increases apoptosis) (Zhi et al. 2012). On the other side, it seems that OS exerts negative effects on Tregs, cells that represent an important peripheral mechanism of immune regulation. Although Treg cells are generally less sensitive to OS than CD4+ cells, due to better antioxidative equipment, high amount of ROS can induce apoptosis of Treg (Maj et al. 2017). Deleterious effects of OS on Treg function have mainly been ascribed to the inhibition of Foxp3 expression. Chronic OS stimulates an overproduction of IL-6, which inhibits Foxp3 expression during Treg differentiation (Yang et al. 2016). Additionally, OS can also promote the enhanced production of NO, mitochondrial hyperpolarization, and $\mathrm{Ca}^{2+}$ influx to the cell, resulting in overexpression of the mechanistic target of rapamycin complex 1 (mTORC1) (Solleiro-Villavicencio and Rivas-Arancibia 2018). This protein complex inhibits the proliferation of Tregs, but also promotes the expansion of Th1 and Th17 proinflammatory lymphocytes (Perl 2016).

\section{Clinical implications: antioxidant therapy in MS}

Considering all the above, there is an ample evidence that OS plays an important role in the pathogenesis of MS. This has given hope that attenuation of OS by antioxidant supplementation can be employed in therapy of MS. However, contrary to promising basic research and preclinical results, the results of clinical trials are still controversial (Adamczyk and AdamczykSowa 2016, Miller et al. 2019, Saso and Firuzi 2014). Currently, a number of clinical trials are on way and hopefully more information will be available when these are completed.

Several explanations for failure of clinical studies examining broadly active antioxidants in MS have been proposed (Lepka et al. 2016, Neves Carvalho et al. 2017, Saso and Firuzi 2014). First of all, it is important to note the difficulty of translation of preclinical results to clinical trials. Although EAE has been useful in elucidation of key pathological processes underlying neuroinflammation, it does not fully reproduce the extent of oxidative injury, neuronal loss and cortical demyelination seen in MS (Witte et al. 2014). Furthermore, many clinical trials have not used validated or appropriate biomarkers of OS, making interpretation of results inconclusive (Neves Carvalho et al. 2017, Saso and Firuzi 2014). When making a design of a clinical trials this has to be considered, in addition to the appropriate dose, and length of supplementation. Bioavailability is another important factor, which should be considered. Failure of antioxidants to reach CNS, that is, to cross BBB will lead to failure to attenuate OS in CNS. Moreover, many clinical trials have evaluated dietary antioxidants. It should be born in mind that the 
majority of antioxidant capacity in the CNS is provided by endogenous enzymes (enzymes controlled by Nrf2: SOD, CAT, GPx etc.) and endogenous compounds (primarily GSH) and not by dietary antioxidants (Neves Carvalho et al. 2017). In addition, many dietary antioxidants do not cross the BBB. In case of mitochondria - targeted antioxidants, the inability to accumulate in mitochondria due to negative charge under physiological conditions, will result in lack of efficacy (Fetisova et al. 2017). Finally, it is plausible that the first attempts in use of antioxidant therapy have failed because specific ROS and RNS which are crucial for the pathology of MS have been neglected (Lepka et al. 2016). In other words, attenuation of specific reactive species of importance to MS pathology, whether by inhibition of pathways responsible for their production or boosting of pathways liable for their scavenging, seems to be more efficient than unspecific application of broadly active antioxidants. In this context, this review highlights specific targets: Nrf2 induction, iNOS, MPO and NOX2 inhibition, scavenging of $\mathrm{ONOO}^{-}$, improving mitochondrial function, enhancing PGC- $1 \alpha$ activity in mitochondria.

\section{Conclusions}

In conclusion, there is an ample evidence that OS plays an important role in the pathogenesis of MS. As there is a strong mutual connection between inflammation, immunity and OS in the pathology of MS, fine modulation of this delicate regulatory network could be an appealing strategy in the treatment of MS.

\section{Conflict of Interest}

There is no conflict of interest.

\section{Acknowledgements}

This work was supported by the Charles University Project Progress Q25.

\section{References}

ABAIS JM, XIA M, ZHANG Y, BOINI KM, LI P-L: Redox regulation of NLRP3 inflammasomes: ROS as trigger or effector? Antioxid Redox Signal 22: 1111-1129, 2015. https://doi.org/10.1089/ars.2014.5994

ABDIN AA, HASBY EA: Modulatory effect of celastrol on Th1/Th2 cytokines profile, TLR2 and CD3+ T-lymphocyte expression in a relapsing-remitting model of multiple sclerosis in rats. Eur J Pharmacol 742: 102-112, 2014. https://doi.org/10.1016/j.ejphar.2014.09.001

ABDULSALAM SF, THOWFEIK FS, MERINO EJ: Excessive reactive oxygen species and exotic DNA lesions as an exploitable liability. Biochemistry 55: 5341-5352, 2016. https://doi.org/10.1021/acs.biochem.6b00703

ADAMCZYK-SOWA M, SOWA P, ADAMCZYK J, NIEDZIELA N, MISIOLEK H, OWCZAREK M, ZWIRSKAKORCZALA K: Effect of melatonin supplementation on plasma lipid hydroperoxides, homocysteine concentration and chronic fatigue syndrome in multiple sclerosis patients treated with interferons-beta and mitoxantrone. J Physiol Pharmacol 67: 235-242, 2016. https://doi.org/10.1016/j.jns.2017.08.671

ADAMCZYK B, ADAMCZYK-SOWA M: New insights into the role of oxidative stress mechanisms in the pathophysiology and treatment of multiple sclerosis. Oxid Med Cell Longev 2016: 1973834, 2016. https://doi.org/10.1155/2016/1973834

BAIRD L, DINKOVA-KOSTOVA AT: The cytoprotective role of the Keap1-Nrf2 pathway. Arch Toxicol 85: 241-272, 2011. https://doi.org/10.1007/s00204-011-0674-5

BARANCIK M, GRESOVA L, BARTEKOVÁ M, DOVINOVÁ I: Nrf2 as a key player of redox regulation in cardiovascular diseases. Physiol Res 65 (Suppl 1): S1-S10, 2016.

BICKER G: Nitric oxide: an unconventional messenger in the nervous system of an orthopteroid insect. Arch Insect Biochem Physiol 48: 100-110, 2001. https://doi.org/10.1002/arch.1062

BLUM L, TAFFERNER N, SPRING I, KURZ J, GEISSLINGER G, PARNHAM MJ, SCHIFFMANN S: Dietary phytol reduces clinical symptoms in experimental autoimmune encephalomyelitis (EAE) at least partially by modulating NOX2 expression. J Mol Med 96: 1131-1144, 2018. https://doi.org/10.1007/s00109-018-1689-7

BRECKWOLDT MO, ARMOUNDAS AA, AON MA, BENDSZUS M, O'ROURKE B, SCHWARZLÄNDER M, DICK TP, KURZ FT: Mitochondrial redox and pH signaling occurs in axonal and synaptic organelle clusters. Sci Rep 6: 23251, 2016. https://doi.org/10.1038/srep23251 
BRECKWOLDT MO, PFISTER FM, BRADLEY PM, MARINKOVIĆ P, WILLIAMS PR, BRILL MS, PLOMER B, SCHMALZ A, ST CLAIR DK, NAUMANN R, GRIESBECK O, SCHWARZLÄNDER M, GODINHO L, BAREYRE FM, DICK TP, KERSCHENSTEINER M, MISGELD T: Multiparametric optical analysis of mitochondrial redox signals during neuronal physiology and pathology in vivo. Nat Med 20: 555-560, 2014. https://doi.org/10.1038/nm.3520

BRIEGER K, SCHIAVONE S, MILLER JR FJ, KRAUSE K-H: Reactive oxygen species: from health to disease. Swiss Med Wkly 142: w13659, 2012. https://doi.org/10.4414/smw.2012.13659

BULUA AC, SIMON A, MADDIPATI R, PELLETIER M, PARK H, KIM K-Y, SACK MN, KASTNER DL, SIEGEL RM: Mitochondrial reactive oxygen species promote production of proinflammatory cytokines and are elevated in TNFR1-associated periodic syndrome (TRAPS). J Exp Med 208: 519-533, 2011. https://doi.org/10.1084/jem.20102049

CADENAS E, BOVERIS A, RAGAN CI, STOPPANI AO: Production of superoxide radicals and hydrogen peroxide by NADH-ubiquinone reductase and ubiquinol-cytochrome c reductase from beef-heart mitochondria. Arch Biochem Biophys 180: 248-257, 1977. https://doi.org/10.1016/0003-9861(77)90035-2

CAMPBELL GR, WORRALL JT, MAHAD DJ: The central role of mitochondria in axonal degeneration in multiple sclerosis. Mult Scler J 20: 1806-1813, 2014. https://doi.org/10.1177/1352458514544537

CAMPBELL GR, ZIABREVA I, REEVE AK, KRISHNAN KJ, REYNOLDS R, HOWELL O, LASSMANN H, TURNBULL DM, MAHAD DJ: Mitochondrial DNA deletions and neurodegeneration in multiple sclerosis. Ann Neurol 69: 481-492, 2011. https://doi.org/10.1002/ana.22109

CARVALHO AN, LIM JL, NIJLAND PG, WITTE ME, VAN HORSSEN J: Glutathione in multiple sclerosis: more than just an antioxidant? Mult Scler J 20: 1425-1431, 2014. https://doi.org/10.1177/1352458514533400

CHECHNEVA OV, MAYRHOFER F, DAUGHERTY DJ, PLEASURE DE, HONG J-S, DENG W: Low dose dextromethorphan attenuates moderate experimental autoimmune encephalomyelitis by inhibiting NOX2 and reducing peripheral immune cells infiltration in the spinal cord. Neurobiol Dis 44: 63-72, 2011. https://doi.org/10.1016/j.nbd.2011.06.004

CHOI BY, KIM JH, KHO AR, KIM IY, LEE SH, LEE BE, CHOI E, SOHN M, STEVENSON M, CHUNG TN: Inhibition of $\mathrm{NADPH}$ oxidase activation reduces EAE-induced white matter damage in mice. J Neuroinflammation 12: 104, 2015. https://doi.org/10.1186/s12974-015-0325-5

DI MEO S, REED TT, VENDITTI P, VICTOR VM: Role of ROS and RNS sources in physiological and pathological conditions. Oxid Med Cell Longev 2016: 1245049, 2016. https://doi.org/10.1155/2016/1245049

DIEBOLD SS: Determination of T-cell fate by dendritic cells. Immunol Cell Biol 86: 389-397, 2008. https://doi.org/10.1038/icb.2008.26

DINKOVA-KOSTOVA AT, ABRAMOV AY: The emerging role of Nrf2 in mitochondrial function. Free Radic Biol Med 88: 179-188, 2015. https://doi.org/10.1016/j.freeradbiomed.2015.04.036

DINKOVA-KOSTOVA AT, KOSTOV RV, KAZANTSEV AG: The role of Nrf2 signaling in counteracting neurodegenerative diseases. FEBS J 285: 3576-3590, 2018. https://doi.org/10.1111/febs.14379

DURAFOURT BA, MOORE CS, ZAMMIT DA, JOHNSON TA, ZAGUIA F, GUIOT MC, BAR-OR A, ANTEL JP: Comparison of polarization properties of human adult microglia and blood-derived macrophages. Glia 60 : 717-727, 2012. https://doi.org/10.1002/glia.22298

DUSEK P, SCHNEIDER SA, AASETH J: Iron chelation in the treatment of neurodegenerative diseases. J Trace Elem Med Biol 38: 81-92, 2016. https://doi.org/10.1016/j.jtemb.2016.03.010

FETISOVA E, CHERNYAK B, KORSHUNOVA G, MUNTYAN M, SKULACHEV V: Mitochondria-targeted antioxidants as a prospective therapeutic strategy for multiple sclerosis. Curr Med Chem 24: 2086-2114, 2017. https://doi.org/10.2174/0929867324666170316114452

FILIPPI M, BRÜCK W, CHARD D, FAZEKAS F, GEURTS JJ, ENZINGER C, HAMETNER S, KUHLMANN T, PREZIOSA P, ROVIRA À: Association between pathological and MRI findings in multiple sclerosis. Lancet Neurol 18: 198-210, 2019. https://doi.org/10.1016/S1474-4422(18)30451-4 
FISCHER MT, SHARMA R, LIM JL, HAIDER L, FRISCHER JM, DREXHAGE J, MAHAD D, BRADL M, VAN HORSSEN J, LASSMANN H: NADPH oxidase expression in active multiple sclerosis lesions in relation to oxidative tissue damage and mitochondrial injury. Brain 135: 886-899, 2012. https://doi.org/10.1093/brain/aws012

FONSECA-KELLY Z, NASSRALLAH M, URIBE J, KHAN RS, DINE K, DUTT M, SHINDLER KS: Resveratrol neuroprotection in a chronic mouse model of multiple sclerosis. Front Neurol 3: 84, 2012. https://doi.org/10.3389/fneur.2012.00084

FORGHANI R, WOJTKIEWICZ GR, ZHANG Y, SEEBURG D, BAUTZ BR, PULLI B, MILEWSKI AR, ATKINSON WL, IWAMOTO Y, ZHANG ER: Demyelinating diseases: myeloperoxidase as an imaging biomarker and therapeutic target. Radiology 263: 451-460, 2012. https://doi.org/10.1148/radiol.12111593

FRISCHER JM, BRAMOW S, DAL-BIANCO A, LUCCHINETTI CF, RAUSCHKA H, SCHMIDBAUER M, LAURSEN H, SORENSEN PS, LASSMANN H: The relation between inflammation and neurodegeneration in multiple sclerosis brains. Brain 132: 1175-1189, 2009. https://doi.org/10.1093/brain/awp070

GENC K, GENC S, BASKIN H, SEMIN I: Erythropoietin decreases cytotoxicity and nitric oxide formation induced by inflammatory stimuli in rat oligodendrocytes. Physiol Res 55: 33-38, 2006.

GRAY E, THOMAS TL, BETMOUNI S, SCOLDING N, LOVE S: Elevated activity and microglial expression of myeloperoxidase in demyelinated cerebral cortex in multiple sclerosis. Brain Pathol 18: 86-95, 2008a. https://doi.org/10.1111/j.1750-3639.2007.00110.x

GRAY E, THOMAS TL, BETMOUNI S, SCOLDING N, LOVE S: Elevated myeloperoxidase activity in white matter in multiple sclerosis. Neurosci Lett 444: 195-198, 2008b. https://doi.org/10.1016/j.neulet.2008.08.035

GRIGORIADIS N, PESCH V: A basic overview of multiple sclerosis immunopathology. Eur J Neurol 22: 3-13, 2015. https://doi.org/10.1111/ene.12798

HAIDER L: Inflammation, iron, energy failure, and oxidative stress in the pathogenesis of multiple sclerosis. Oxid Med Cell Longev 2015: 725370, 2015. https://doi.org/10.1155/2015/725370

HALLGREN B, SOURANDER P: The effect of age on the non-haemin iron in the human brain. J Neurochem 3: 41-51, 1958. https://doi.org/10.1111/j.1471-4159.1958.tb12607.x

HALLIWELL B, GUTTERIDGE J: Oxygen toxicity, oxygen radicals, transition metals and disease. Biochem J 219: 1, 1984. https://doi.org/10.1042/bj2190001

HAMETNER S, WIMMER I, HAIDER L, PFEIFENBRING S, BRÜCK W, LASSMANN H: Iron and neurodegeneration in the multiple sclerosis brain. Ann Neurol 74: 848-861, 2013. https://doi.org/10.1002/ana.23974

HØIVIK HO, LAURIJSSENS BE, HARNISCH LO, TWOMEY CK, DIXON RM, KIRKHAM AJ, WILLIAMS PM, WENTZ AL, LUNNON MW: Lack of efficacy of the selective iNOS inhibitor GW274150 in prophylaxis of migraine headache. Cephalalgia 30: 1458-1467, 2010. https://doi.org/10.1177/0333102410370875

HONDARES E, MORA O, YUBERO P, DE LA CONCEPCIÓN MR, IGLESIAS R, GIRALT M, VILLARROYA F: Thiazolidinediones and rexinoids induce peroxisome proliferator-activated receptor-coactivator (PGC)-1 $\alpha$ gene transcription: an autoregulatory loop controls PGC-1 $\alpha$ expression in adipocytes via peroxisome proliferatoractivated receptor- $\gamma$ coactivation. Endocrinology 147: 2829-2838, 2006. https://doi.org/10.1210/en.2006-0070

HONORAT JA, KINOSHITA M, OKUNO T, TAKATA K, KODA T, TADA S, SHIRAKURA T, FUJIMURA H, MOCHIZUKI H, SAKODA S: Xanthine oxidase mediates axonal and myelin loss in a murine model of multiple sclerosis. PLoS One 8: e71329, 2013. https://doi.org/10.1371/journal.pone.0071329

HONORAT JA, NAKATSUJI Y, SHIMIZU M, KINOSHITA M, SUMI-AKAMARU H, SASAKI T, TAKATA K, KODA T, NAMBA A, YAMASHITA K, SANDA E, SAKAGUCHI M, KUMANOGOH A, SHIRAKURA T, TAMURA M, SAKODA S, MOCHIZUKI H, OKUNO T: Febuxostat ameliorates secondary progressive experimental autoimmune encephalomyelitis by restoring mitochondrial energy production in a GOT2dependent manner. PLoS One 12: e0187215, 2017. https://doi.org/10.1371/journal.pone.0187215

HUBERT MT, THAYER TC, STEELE C, CUDA CM, MOREL L, PIGANELLI JD, MATHEWS CE: NADPH oxidase deficiency regulates Th lineage commitment and modulates autoimmunity. J Immunol 185: 5247-5258, 2010. https://doi.org/10.4049/jimmunol.1001472 
HULET S, POWERS S, CONNOR J: Distribution of transferrin and ferritin binding in normal and multiple sclerotic human brains. J Neurol Sci 165: 48-55, 1999. https://doi.org/10.1016/S0022-510X(99)00077-5

JACK C, ANTEL J, BRÜCK W, KUHLMANN T: Contrasting potential of nitric oxide and peroxynitrite to mediate oligodendrocyte injury in multiple sclerosis. Glia 55: 926-934, 2007. https://doi.org/10.1002/glia.20514

JIANG X-M, HU J-H, WANG L-L, MA C, WANG X, LIU X-L: Ulinastatin alleviates neurological deficiencies evoked by transient cerebral ischemia via improving autophagy, Nrf-2-ARE and apoptosis signals in hippocampus. Physiol Res 67: 637-646, 2018. https://doi.org/10.33549/physiolres.933780

JOHNSON DA, AMIRAHMADI S, WARD C, FABRY Z, JOHNSON JA: The absence of the pro-antioxidant transcription factor Nrf2 exacerbates experimental autoimmune encephalomyelitis. Toxicol Sci 114: 237-246, 2009. https://doi.org/10.1093/toxsci/kfp274

KATSUOKA F, YAMAMOTO M: Small Maf proteins (MafF, MafG, MafK): history, structure and function. Gene 586: 197-205, 2016. https://doi.org/10.1016/j.gene.2016.03.058

KIM GH, KIM JE, RHIE SJ, YOON S: The role of oxidative stress in neurodegenerative diseases. Exp Neurobiol 24 : 325-340, 2015. https://doi.org/10.5607/en.2015.24.4.325

KWAK M-K, WAKABAYASHI N, ITOH K, MOTOHASHI H, YAMAMOTO M, KENSLER TW: Modulation of gene expression by cancer chemopreventive dithiolethiones through the Keap1-Nrf2 pathway identification of novel gene clusters for cell survival. J Biol Chem 278: 8135-8145, 2003. https://doi.org/10.1074/jbc.M211898200

LAN M, TANG X, ZHANG J, YAO Z: Insights in pathogenesis of multiple sclerosis: nitric oxide may induce mitochondrial dysfunction of oligodendrocytes. Rev Neuroscience 29: 39-53, 2017. https://doi.org/10.1515/revneuro-2017-0033

LANG Y, CHU F, SHEN D, ZHANG W, ZHENG C, ZHU J, CUI L: Role of inflammasomes in neuroimmune and neurodegenerative diseases: a systematic review. Mediators Inflamm 2018: 1549549, 2018. https://doi.org/10.1155/2018/1549549

LASSMANN H, VAN HORSSEN J: Oxidative stress and its impact on neurons and glia in multiple sclerosis lesions. Biochim Biophys Acta 1862: 506-510, 2016. https://doi.org/10.1016/j.bbadis.2015.09.018

LEE J-M, CALKINS MJ, CHAN K, KAN YW, JOHNSON JA: Identification of the NF-E2-related factor-2-dependent genes conferring protection against oxidative stress in primary cortical astrocytes using oligonucleotide microarray analysis. J Biol Chem 278: 12029-12038, 2003. https://doi.org/10.1074/jbc.M211558200

LEPKA K, BERNDT C, HARTUNG H-P, AKTAS O: Redox events as modulators of pathology and therapy of neuroinflammatory diseases. Front Cell Dev Biol 4: 63, 2016. https://doi.org/10.3389/fcell.2016.00063

LEPKA K, VOLBRACHT K, BILL E, SCHNEIDER R, RIOS N, HILDEBRANDT T, INGWERSEN J, PROZOROVSKI T, LILLIG CH, VAN HORSSEN J: Iron-sulfur glutaredoxin 2 protects oligodendrocytes against damage induced by nitric oxide release from activated microglia. Glia 65: 1521-1534, 2017. https://doi.org/10.1002/glia.23178

LEPPERT D, WAUBANT E, GALARDY R, BUNNETT NW, HAUSER SL: T cell gelatinases mediate basement membrane transmigration in vitro. J Immunol 154: 4379-4389, 1995.

LI B, CUI W, LIU J, LI R, LIU Q, XIE X-H, GE X-L, ZHANG J, SONG X-J, WANG Y: Sulforaphane ameliorates the development of experimental autoimmune encephalomyelitis by antagonizing oxidative stress and Th17related inflammation in mice. Exp Neurol 250: 239-249, 2013. https://doi.org/10.1016/j.expneurol.2013.10.002

LI S, VANA A, RIBEIRO R, ZHANG Y: Distinct role of nitric oxide and peroxynitrite in mediating oligodendrocyte toxicity in culture and in experimental autoimmune encephalomyelitis. Neuroscience 184: 107-119, 2011. https://doi.org/10.1016/j.neuroscience.2011.04.007

LIDDELL J: Are astrocytes the predominant cell type for activation of Nrf2 in aging and neurodegeneration? Antioxidants 6: 65, 2017. https://doi.org/10.3390/antiox6030065

LICHT-MAYER S, WIMMER I, TRAFFEHN S, METZ I, BRÜCK W, BAUER J, BRADL M, LASSMANN H: Cell type-specific Nrf2 expression in multiple sclerosis lesions. Acta Neuropathol 130: 263-277, 2015. https://doi.org/10.1007/s00401-015-1452-x 
LONG T, YANG Y, PENG L, LI Z: Neuroprotective effects of melatonin on experimental allergic encephalomyelitis mice via anti-oxidative stress activity. J Mol Neurosci 64: 233-241, 2018. https://doi.org/10.1007/s12031-017$\underline{1022-\mathrm{X}}$

LORENZ M, PAUL F, MOOBED M, BAUMANN G, ZIMMERMANN BF, STANGL K, STANGL V: The activity of catechol-O-methyltransferase (COMT) is not impaired by high doses of epigallocatechin-3-gallate (EGCG) in vivo. Eur J Pharmacol 740: 645-651, 2014. https://doi.org/10.1016/j.ejphar.2014.06.014

LOVERA J, RAMOS A, DEVIER D, GARRISON V, KOVNER B, REZA T, KOOP D, ROONEY W, FOUNDAS A, BOURDETTE D: Polyphenon E, non-futile at neuroprotection in multiple sclerosis but unpredictably hepatotoxic: phase I single group and phase II randomized placebo-controlled studies. J Neurol Sci 358: 46-52, 2015. https://doi.org/10.1016/j.jns.2015.08.006

MA MW, WANG J, ZHANG Q, WANG R, DHANDAPANI KM, VADLAMUDI RK, BRANN DW: NADPH oxidase in brain injury and neurodegenerative disorders. Mol Neurodegener 12: 7, 2017. https://doi.org/10.1186/s13024-017-0150-7

MAHAD D, ZIABREVA I, LASSMANN H, TURNBULL D: Mitochondrial defects in acute multiple sclerosis lesions. Brain 131: 1722-1735, 2008. https://doi.org/10.1093/brain/awn105

MAHAD DH, TRAPP BD, LASSMANN H: Pathological mechanisms in progressive multiple sclerosis. Lancet Neurol 14: 183-193, 2015. https://doi.org/10.1016/S1474-4422(14)70256-X

MÄHLER A, STEINIGER J, BOCK M, KLUG L, PARREIDT N, LORENZ M, ZIMMERMANN BF, KRANNICH A, PAUL F, BOSCHMANN M: Metabolic response to epigallocatechin-3-gallate in relapsing-remitting multiple sclerosis: a randomized clinical trial. Am J Clin Nutr 101: 487-495, 2015. https://doi.org/10.3945/ajcn.113.075309

MAJ T, WANG W, CRESPO J, ZHANG H, WANG W, WEI S, ZHAO L, VATAN L, SHAO I, SZELIGA W: Oxidative stress controls regulatory $\mathrm{T}$ cell apoptosis and suppressor activity and PD-L1-blockade resistance in tumor. Nat Immunol 18: 1332, 2017. https://doi.org/10.1038/ni.3868

MANDER P, BORUTAITE V, MONCADA S, BROWN GC: Nitric oxide from inflammatory-activated glia synergizes with hypoxia to induce neuronal death. J Neurosci Res 79: 208-215, 2005. https://doi.org/10.1002/jnr.20285

MENESHIAN A, BULKLEY GB: The physiology of endothelial xanthine oxidase: from urate catabolism to reperfusion injury to inflammatory signal transduction. Microcirculation 9: 161-175, 2002. https://doi.org/10.1038/sj.mn.7800136

MENG D, SHI X, JIANG B-H, FANG J: Insulin-like growth factor-I (IGF-I) induces epidermal growth factor receptor transactivation and cell proliferation through reactive oxygen species. Free Radic Biol Med 42: 1651-1660, 2007. https://doi.org/10.1016/j.freeradbiomed.2007.01.037

MIAO H, XU J, XU D, MA X, ZHAO X, LIU L: Nociceptive behavior induced by chemotherapeutic paclitaxel and beneficial role of antioxidative pathways. Physiol Res 68: 491-500, 2019. https://doi.org/10.33549/physiolres.933939

MICHALICKOVA D, KOTUR-STEVULJEVIC J, MILJKOVIC M, DIKIC N, KOSTIC-VUCICEVIC M, ANDJELKOVIC M, KORICANAC V, DJORDJEVIC B: Effects of probiotic supplementation on selected parameters of blood prooxidant-antioxidant balance in elite athletes: a double-blind randomized placebo-controlled study. J Hum Kinet 64: 111-122, 2018. https://doi.org/10.1515/hukin-2017-0203

MICHALIČKOVÁ D, BELOVIĆ M, ILIĆ N, KOTUR-STEVULJEVIĆ J, SLANAŘ O, ŠOBAJIĆ S: Comparison of polyphenol-enriched tomato juice and standard tomato juice for cardiovascular benefits in subjects with stage 1 hypertension: a randomized controlled study. Plant Food Hum Nutr 74: 122-127, 2019. https://doi.org/10.1007/s11130-019-0714-5

MILLER ED, DZIEDZIC A, SALUK-BIJAK J, BIJAK M: A review of various antioxidant compounds and their potential utility as complementary therapy in multiple sclerosis. Nutrients 11: 1528, 2019. https://doi.org/10.3390/nu11071528

MIN W, CHEN Y, ZHOU Z: Mitochondria, oxidative stress and innate immunity. Front Physiol 9: $1487,2018$. https://doi.org/10.3389/fphys.2018.01487

MIRSHAFIEY A, MOHSENZADEGAN M: Antioxidant therapy in multiple sclerosis. Immunopharm Immunot 31: 13-29, 2009. https://doi.org/10.1080/08923970802331943 
MOHAJERI M, SADEGHIZADEH M, NAJAFI F, JAVAN M: Polymerized nano-curcumin attenuates neurological symptoms in EAE model of multiple sclerosis through down regulation of inflammatory and oxidative processes and enhancing neuroprotection and myelin repair. Neuropharmacology 99: 156-167, 2015. https://doi.org/10.1016/j.neuropharm.2015.07.013

MORIYA M, NAKATSUJI Y, MIYAMOTO K, OKUNO T, KINOSHITA M, KUMANOGOH A, KUSUNOKI S, SAKODA S: Edaravone, a free radical scavenger, ameliorates experimental autoimmune encephalomyelitis. Neurosci Lett 440: 323-326, 2008. https://doi.org/10.1016/j.neulet.2008.05.110

MUTHIAN G, BRIGHT JJ: Quercetin, a flavonoid phytoestrogen, ameliorates experimental allergic encephalomyelitis by blocking IL-12 signaling through JAK-STAT pathway in T lymphocyte. J Clin Immunol 24: 542-552, 2004. https://doi.org/10.1023/B:JOCI.0000040925.55682.a5

NEHER JJ, NENISKYTE U, ZHAO J-W, BAL-PRICE A, TOLKOVSKY AM, BROWN GC: Inhibition of microglial phagocytosis is sufficient to prevent inflammatory neuronal death. J Immunol 186: 4973-4983, 2011. https://doi.org/10.4049/jimmunol.1003600

NEVES CARVALHO A, FIRUZI O, JOAO GAMA M, VAN HORSSEN J, SASO L: Oxidative stress and antioxidants in neurological diseases: is there still hope? Curr Drug Targets 18: 705-718, 2017. https://doi.org/10.2174/1389450117666160401120514

NIJLAND PG, WITTE ME, VAN HET HOF B, VAN DER POL S, BAUER J, LASSMANN H, VAN DER VALK P, DE VRIES HE, VAN HORSSEN J: Astroglial PGC-1alpha increases mitochondrial antioxidant capacity and suppresses inflammation: implications for multiple sclerosis. Acta Neuropathol Commun 2: 170, 2014. https://doi.org/10.1186/s40478-014-0170-2

NOUBADE R, WONG K, OTA N, RUTZ S, EIDENSCHENK C, VALDEZ PA, DING J, PENG I, SEBRELL A, CAPLAZI P: NRROS negatively regulates reactive oxygen species during host defence and autoimmunity. Nature 509: 235, 2014. https://doi.org/10.1038/nature13152

OCKELFORD F, SAADA L, GAZIT E, DE MEL A: Is nitric oxide assuming a Janus-face in the central nervous system? Curr Med Chem 23: 1625-1637, 2016. https://doi.org/10.2174/0929867323666160316124137

OHL K, TENBROCK K, KIPP M: Oxidative stress in multiple sclerosis: central and peripheral mode of action. Exp Neurol 277: 58-67, 2016. https://doi.org/10.1016/j.expneurol.2015.11.010

ONTANEDA D, THOMPSON AJ, FOX RJ, COHEN JA: Progressive multiple sclerosis: prospects for disease therapy, repair, and restoration of function. Lancet 389: 1357-1366, 2017. https://doi.org/10.1016/S01406736(16)31320-4

OW Y-LP, GREEN DR, HAO Z, MAK TW: Cytochrome c: functions beyond respiration. Nat Rev Mol Cell Biol 9: 532-542, 2008. https://doi.org/10.1038/nrm2434

PAJARES M, JIMÉNEZ-MORENO N, GARCÍA-YAGÜE ÁJ, ESCOLL M, DE CEBALLOS ML, VAN LEUVEN F, RÁBANO A, YAMAMOTO M, ROJO AI, CUADRADO A: Transcription factor NFE2L2/NRF2 is a regulator of macroautophagy genes. Autophagy 12: 1902-1916, 2016. https://doi.org/10.1080/15548627.2016.1208889

PANDIT A, VADNAL J, HOUSTON S, FREEMAN E, MCDONOUGH J: Impaired regulation of electron transport chain subunit genes by nuclear respiratory factor 2 in multiple sclerosis. J Neurol Sci 279: 14-20, 2009. https://doi.org/10.1016/j.jns.2009.01.009

PANG Y, CAMPBELL L, ZHENG B, FAN L, CAI Z, RHODES P: Lipopolysaccharide-activated microglia induce death of oligodendrocyte progenitor cells and impede their development. Neuroscience 166: 464-475, 2010. https://doi.org/10.1016/j.neuroscience.2009.12.040

PAUL BD, SNYDER SH: Impaired redox signaling in Huntington's disease: therapeutic implications. Front Mol Neurosci 12: 68, 2019. https://doi.org/10.3389/fnmol.2019.00068

PENESOVÁ A, DEAN Z, KOLLÁR B, HAVRANOVÁ A, IMRICH R, VLČEK M, RÁDIKOVÁ Ž: Nutritional intervention as an essential part of multiple sclerosis treatment? Physiol Res 67: 521-533, 2018. https://doi.org/10.33549/physiolres.933694

PERL A: Activation of mTOR (mechanistic target of rapamycin) in rheumatic diseases. Nat Rev Rheumatol 12: 169, 2016. https://doi.org/10.1038/nrrheum.2015.172 
QI W, LI J, CHAIN C, PASQUEVICH G, PASQUEVICH A, COWAN J: Glutathione complexed Fe-S centers. J Am Chem Soc 134: 10745-10748, 2012. https://doi.org/10.1021/ja302186j

ROJO AI, MCBEAN G, CINDRIC M, EGEA J, LÓPEZ MG, RADA P, ZARKOVIC N, CUADRADO A: Redox control of microglial function: molecular mechanisms and functional significance. Antioxid Redox Signal 21: 1766-1801, 2014. https://doi.org/10.1089/ars.2013.5745

SAJAD M, ZARGAN J, CHAWLA R, UMAR S, SADAQAT M, KHAN HA: Hippocampal neurodegeneration in experimental autoimmune encephalomyelitis (EAE): potential role of inflammation activated myeloperoxidase. Mol Cell Biochem 328: 183-188, 2009. https://doi.org/10.1007/s11010-009-0088-3

SALIM S: Oxidative stress and the central nervous system. J Pharmacol Exp Ther 360: 201-205, 2017. https://doi.org/10.1124/jpet.116.237503

SASO L, FIRUZI O: Pharmacological applications of antioxidants: lights and shadows. Curr Drug Targets 15: 1177-1199, 2014. https://doi.org/10.2174/1389450115666141024113925

SEMNANI M, MASHAYEKHI F, AZARNIA M, SALEHI Z: Effects of green tea epigallocatechin-3-gallate on the proteolipid protein and oligodendrocyte transcription factor 1 messenger RNA gene expression in a mouse model of multiple sclerosis. Folia Neuropathol 55: 199-205, 2017. https://doi.org/10.5114/fn.2017.70484

SHADEL GS, HORVATH TL: Mitochondrial ROS signaling in organismal homeostasis. Cell 163: 560-569, 2015. https://doi.org/10.1016/j.cell.2015.10.001

SHEYKHANSARI S, KOZIELSKI K, BILL J, SITTI M, GEMMATI D, ZAMBONI P, SINGH AV: Redox metals homeostasis in multiple sclerosis and amyotrophic lateral sclerosis: a review. Cell Death Dis 9: 348, 2018. https://doi.org/10.1038/s41419-018-0379-2

SHINDLER KS, VENTURA E, DUTT M, ELLIOTT P, FITZGERALD DC, ROSTAMI A: Oral resveratrol reduces neuronal damage in a model of multiple sclerosis. J Neuroophthalmol 30: 328-339, 2010. https://doi.org/10.1097/WNO.0b013e3181f7f833

SHOKEIR AA, BARAKAT N, HUSSEIN AM, AWADALLA A, HARRAZ A, KHATER S, HEMMAID K, KAMAL AI: Activation of Nrf2 by ischemic preconditioning and sulforaphane in renal ischemia/reperfusion injury: a comparative experimental study. Physiol Res 64: 313-323, 2015.

SCHMALBROCK P, PRAKASH R, SCHIRDA B, JANSSEN A, YANG G, RUSSELL M, KNOPP M, BOSTER A, NICHOLAS J, RACKE M: Basal ganglia iron in patients with multiple sclerosis measured with 7T quantitative susceptibility mapping correlates with inhibitory control. Am J Neuroradiol 37: 439-446, 2016. https://doi.org/10.3174/ajnr.A4599

SIES H, BERNDT C, JONES DP: Oxidative stress. Annu Rev Biochem 86: 715-748, 2017. https://doi.org/10.1146/annurev-biochem-061516-045037

SINGHAL G, JAEHNE EJ, CORRIGAN F, TOBEN C, BAUNE BT: Inflammasomes in neuroinflammation and changes in brain function: a focused review. Front Neurosci 8: 315, 2014. https://doi.org/10.3389/fnins.2014.00315

SOLLEIRO-VILLAVICENCIO H, RIVAS-ARANCIBIA S: Effect of chronic oxidative stress on neuroinflammatory response mediated by CD4 $+\mathrm{T}$ cells in neurodegenerative diseases. Front Cell Neurosci 12, 2018. https://doi.org/10.3389/fncel.2018.00114

STEPHENSON E, NATHOO N, MAHJOUB Y, DUNN JF, YONG VW: Iron in multiple sclerosis: roles in neurodegeneration and repair. Nat Rev Neurol 10: 459-468, 2014. https://doi.org/10.1038/nrneurol.2014.118

STOVER JF, BELLI A, BORET H, BULTERS D, SAHUQUILLO J, SCHMUTZHARD E, ZAVALA E, UNGERSTEDT U, SCHINZEL R, TEGTMEIER F: Nitric oxide synthase inhibition with the antipterin VAS203 improves outcome in moderate and severe traumatic brain injury: a placebo-controlled randomized Phase IIa trial (NOSTRA). J Neurotrauma 31: 1599-1606, 2014. https://doi.org/10.1089/neu.2014.3344

STYS PK: General mechanisms of axonal damage and its prevention. J Neurol Sci 233: 3-13, 2005. https://doi.org/10.1016/j.jns.2005.03.031

TEJERO J, SHIVA S, GLADWIN MT: Sources of vascular nitric oxide and reactive oxygen species and their regulation. Physiol Rev 99: 311-379, 2018. https://doi.org/10.1152/physrev.00036.2017

VALACCHI G, VIRGILI F, CERVELLATI C, PECORELLI A: OxInflammation: From subclinical condition to pathological biomarker. Front Physiol 9: 858, 2018. https://doi.org/10.3389/fphys.2018.00858 
VAN DEN HOOGEN WJ, LAMAN JD, 'T HART BA: Modulation of multiple sclerosis and its animal model experimental autoimmune encephalomyelitis by food and gut microbiota. Front Immunol 8: 1081, 2017. https://doi.org/10.3389/fimmu.2017.01081

VAN DER SCHUEREN B, LUNNON M, LAURIJSSENS B, GUILLARD F, PALMER J, VAN HECKEN A, DEPRÉ M, VANMOLKOT F, DE HOON J: Does the unfavorable pharmacokinetic and pharmacodynamic profile of the iNOS inhibitor GW273629 lead to inefficacy in acute migraine? J Clin Pharmacol 49: 281-290, 2009. https://doi.org/10.1177/0091270008329548

VAN DER VEEN BS, DE WINTHER MP, HEERINGA P: Myeloperoxidase: molecular mechanisms of action and their relevance to human health and disease. Antioxid Redox Signal 11: 2899-2937, 2009. https://doi.org/10.1089/ars.2009.2538

VAN HORSSEN J, DREXHAGE JA, FLOR T, GERRITSEN W, VAN DER VALK P, DE VRIES HE: Nrf2 and DJ1 are consistently upregulated in inflammatory multiple sclerosis lesions. Free Radic Biol Med 49: 1283-1289, 2010. https://doi.org/10.1016/j.freeradbiomed.2010.07.013

VAN HORSSEN J, SCHREIBELT G, DREXHAGE J, HAZES T, DIJKSTRA C, VAN DER VALK P, DE VRIES H: Severe oxidative damage in multiple sclerosis lesions coincides with enhanced antioxidant enzyme expression. Free Radic Biol Med 45: 1729-1737, 2008. https://doi.org/10.1016/j.freeradbiomed.2008.09.023

WINYARD PG, BLAKE DR: Antioxidants, redox-regulated transcription factors, and inflammation. Adv Pharmacol 38: 403-421, 1997. https://doi.org/10.1016/S1054-3589(08)60993-X

WITTE ME, MAHAD DJ, LASSMANN H, VAN HORSSEN J: Mitochondrial dysfunction contributes to neurodegeneration in multiple sclerosis. Trends Mol Med 20: 179-187, 2014. https://doi.org/10.1016/j.molmed.2013.11.007

WITTE ME, NIJLAND PG, DREXHAGE JA, GERRITSEN W, GEERTS D, VAN HET HOF B, REIJERKERK A, DE VRIES HE, VAN DER VALK P, VAN HORSSEN J: Reduced expression of PGC-1 $\alpha$ partly underlies mitochondrial changes and correlates with neuronal loss in multiple sclerosis cortex. Acta Neuropathol 125: 231-243, 2013. https://doi.org/10.1007/s00401-012-1052-y

YANG H, LIU C, JIANG J, WANG Y, ZHANG X: Celastrol attenuates multiple sclerosis and optic neuritis in an experimental autoimmune encephalomyelitis model. Front Pharmacol 8: 44, 2017. https://doi.org/10.3389/fphar.2017.00044

YANG P, MANAENKO A, XU F, MIAO L, WANG G, HU X, GUO Z-N, HU Q, HARTMAN RE, PEARCE WJ: Role of PDGF-D and PDGFR- $\beta$ in neuroinflammation in experimental ICH mice model. Exp Neurol 283: 157-164, 2016. https://doi.org/10.1016/j.expneurol.2016.06.010

ZARRUK JG, BERARD JL, DOS SANTOS RP, KRONER A, LEE J, AROSIO P, DAVID S: Expression of iron homeostasis proteins in the spinal cord in experimental autoimmune encephalomyelitis and their implications for iron accumulation. Neurobiol Dis 81: 93-107, 2015. https://doi.org/10.1016/j.nbd.2015.02.001

ZHANG DD, LO S-C, CROSS JV, TEMPLETON DJ, HANNINK M: Keap1 is a redox-regulated substrate adaptor protein for a Cul3-dependent ubiquitin ligase complex. Mol Cell Biol 24: 10941-10953, 2004. https://doi.org/10.1128/MCB.24.24.10941-10953.2004

ZHANG H, RAY A, MILLER NM, HARTWIG D, PRITCHARD KA, DITTEL BN: Inhibition of myeloperoxidase at the peak of experimental autoimmune encephalomyelitis restores blood-brain barrier integrity and ameliorates disease severity. J Neurochem 136: 826-836, 2016. https://doi.org/10.1111/jnc.13426

ZHI L, USTYUGOVA IV, CHEN X, ZHANG Q, WU MX: Enhanced Th17 differentiation and aggravated arthritis in IEX-1-deficient mice by mitochondrial reactive oxygen species-mediated signaling. J Immunol 189: 1639-1647, 2012. https://doi.org/10.4049/jimmunol.1200528

ZHOU R, YAZDI AS, MENU P, TSCHOPP J: A role for mitochondria in NLRP3 inflammasome activation. Nature 469: 221, 2011. https://doi.org/10.1038/nature09663 